\title{
Antioxidant-Free Radical Scavenging of Some Euphorbiaceae Herbs
}

\author{
Titik Sunarni and Fransiska Leviana \\ Faculty of Pharmacy, Setia Budi University
}

\begin{abstract}
In order to screen natural antioxidant, the research about antioxidant of some Euphobiaceae herbs, have been conducted. The air-dried herbs of Euphorbia heterophylla L, Phyllanthus acidus (L.) Skeels, and Phyllanthus buxifolius Muell Arg were extracted with metanol. The obtained extract was concentrated and then suspended to produce $n$-hexane, ethyl acetat and aqueous fractions. Free radical scavenger activity against DPPH (I,Idiphenyl-2-pycrylhydrazyl) measured by spectrophotometric method and the IC50 value was determined. The compounds of active fraction had been identified by TLC method. All of the herbs showed activity as DPPH scavenger. Among these herbs, Euphorbia heterophylla L. and Phyllanthus buxifolius Muell, Arg. exhibited a strong free radical scavenging of ethyl acetat fraction with $\mathrm{IC}_{50}$ value $5,88 \mu \mathrm{g} / \mathrm{ml}$ and $4,64 \mu \mathrm{g} / \mathrm{ml}$. The result of TLC by mobile phase $n$-buthanol-acetic acid-water (4:1:5) and acetic acid I5\% showed flavonoid compound.
\end{abstract}

Keywords: Euphorbiaceae herbs, antioxidant, DPPH, flavonoid

\section{INTRODUCTION}

Phyllanthus acidus (L.) Skeels, Phyllanthus buxifolius Muell, Arg., Euphorbia heterophylla $L$. belongs to family Euphorbiaceae, also known as ceremai, seligi and katemas, repectively. The herbs heve been used in Indonesian folk medicine for treatment of antiinflammatory, analgetic, laxative and cough. However, the potential of higher plants as sources for new drugs is still largely unexplored. Recent interest in the study of antioxidant may be connected with efficacy of these compounds to cure the most diseases.

Antioxidants are radical scavenging which protect the human body against free radical that may cause phathological conditions such as ischemia, anemia, asthma, arthritis, inflamation, degenerative syndromes and ageing process (Oke and Hambuger, 2002; Bartosikova et al., 2003). The oxygen comsumption inherent in cell growth leads to the generation of a series of reactive oxygen species (ROS). These ROS are molecules such as a superoxide anion radicals $\left(\mathrm{O}^{2} \cdot\right)$ and hydroxyl radicals $\left(\mathrm{OH}^{\cdot}\right)$. However, non-free radical species such as hydrogen peroxide $\left(\mathrm{H}_{2} \mathrm{O}_{2}\right)$ and singled oxygen $\left({ }^{1} \mathrm{O}_{2}\right)$ are formed in vivo.
Both oxygen species play a positive role in energy production, phagocytosis, regulation of cell growth intercellular signaling, and synthesis of biologically important compounds (Gulcin et al., 2004). However, ROS may also be very damaging; they can attack the lipids of cell membranes and DNA. The oxidation induced by ROS can result in cell membrane disintegration, membrane protein damage and DNA mutation, which can further initiate or propagate the development of many diseases (Gulcin et al., 2004; Cos et al., 2000 and Bergman et al., 2001).

Flavonoid are groups of naturally occuring compounds widely distributed, as secondary metabolites in the plant kingdom. These flavonoid have also been report to possess antioxidant and antiradical properties. The scavenging properties of antioxidants are often associated with their ability to form stable radicals.

\footnotetext{
*Corresponding author e-mail: titiksunarni@yahoo.co.id
} 
Also, it is well known that aromatic compounds containing hydroxyl groups, especially those having ortho-di- or trihydroxyl functions can give rise to radical stable enough to be detected by spectroscopy (Gulcin et al., 2004 and Pokorny et al., 2001).

The DPPH test provided information on the reactivity of test compounds with a stable free radical. Because of its odd electron, DPPH (1,1 diphenyl-2-pycrylhydrazyl) give a strong absorption band at $517 \mathrm{~nm}$ in visible spectroscopy (deep violet colour). As the electron become paired off in the presence of a free radical scavenger, the absorption varnishes, thus the resulting decolorization is stoichiometric with respect to the number of electrons taken up (Oke dan Hamburger, 2002; Yagi et al., 2002).

\section{METHODS}

\section{Instruments and reagents}

Shimadzu UV-Vis Spectrophotometry, vacuum rotary evaporator, Thin-layer chromatography plates coated with celulose from Merck, DPPH (1,1-diphenyl-2-picrylhydrazyl from Sigma Co. (St. Louis, USA). All solvents were routinely distilled prior to use. Other reagent were analytical grade.

\section{Plant materials}

The all plant material, were collected and classified by B2P2TO2T (Center for Research and Development of Medicinal Plants and Traditional Medicine) Tawangmangu, Karanganyar, Central of Java.

\section{Extracts preparation and fractination of plant materials}

Plant material was dried, before being powdered and sieved. Plant material was macerated with methanol at room temperatur during 5 days. The extract was concentrated under reduced pressure to produce methanolic extract. This Methanolic extract was suspended in hot water and then partitioned successively with $n$-hexane, EtOAc. Each fraction was evaporated in vacuum to yield the residues of $n$ hexane fraction, ethyl acetate fraction, aquous fraction. Experimental procedure for P. acidus, $P$. buxifolius was leaving a residual water insoluble fraction.

\section{DPPH radical scavenging activity}

The scavenging activity was corresponded to the intensity quenching DPPH radical (Kwon and Kim, 2003) Four $\mathrm{mL}$ of methanol solution of test fractions at various concentration was added to a solution of DPPH $0,45 \mathrm{mM}$ in $\mathrm{MeOH}$ $(1 \mathrm{~mL})$, and the reaction mixture (total volume, 5 $\mathrm{mL}$ ) was shaken vigorously. After storage at room temperature for $30 \mathrm{~min}$, the remaining DPPH was determined by spectrophotometry at $517 \mathrm{~nm}$, and the radical scavenging activity of each sample was expressed by the ratio of the reduction in DPPH absorption (\%), relative to the absorption (100\%) of DPPH solution in the absence of test sample (control). The mean values were obtained by triplicate experiments.

\section{Identification of flavonoid compounds}

Thin layer chromatography were used for analysis of flavonoid. The all fractions was doing identification on celulose with solvent $n$ butanol:acetic acid: water (4:1:5) and acetic acid $15 \%$. The spots was detected by UV $366 \mathrm{~nm}$, ammonia vapor and citroborat spray reagent.

\section{RESULTS}

This work reports the antioxidants activity of the leaves of Phyllanthus buxifolius Muell, Arg, Phyllanthus acidus (L.) Skeels and herbs of Euphorbia heterophylla L.The result of the experiment extraction and fractination is shown in Table 1 and DPPH radical scavenging activities is shown in Table 2. 
Table I. The rendemen extraction of plant material and fractionation of extracts

\begin{tabular}{ccccccc}
\hline & & \multicolumn{5}{c}{ Yields (\%) } \\
\cline { 3 - 6 } No & Material & $\begin{array}{c}\text { methanolic } \\
\text { Extract }\end{array}$ & $\begin{array}{c}\text { n-hexane } \\
\text { fraction }\end{array}$ & $\begin{array}{c}\text { ethyl } \\
\text { acetate } \\
\text { fraction }\end{array}$ & $\begin{array}{c}\text { aquous } \\
\text { fraction }\end{array}$ & $\begin{array}{c}\text { Insoluble } \\
\text { fraction }\end{array}$ \\
\hline I & P. acidus (400 mg) & 11.29 & 20.84 & 9.22 & 47.40 & 6.13 \\
2 & P. buxifolius (400 mg) & 10.08 & 21.78 & 11.61 & 21.85 & 13.48 \\
3 & E.heterophylla (400 mg) & 10.13 & 60.14 & 7.46 & 45.56 & - \\
\hline
\end{tabular}

Table 2. DPPH radical scavenging activities

\begin{tabular}{ccccc}
\hline No & Sample & P. acidus & $\begin{array}{c}\text { IC } \\
\text { P.buxifolius }\end{array}$ & E.heterophylla \\
\hline I & Rutin & 5.11 & 5.11 & 5.11 \\
2 & methanolic extract & 113.30 & 11.56 & 44.43 \\
3 & n-hexane fraction & 306.03 & 115.53 & 212.81 \\
4 & ethyl acetate fraction & 26.61 & 4.64 & 5.88 \\
5 & aquous fraction & 162.03 & 23.83 & 130.63 \\
6 & insoluble fraction & 169.30 & 7.75 & - \\
\hline
\end{tabular}

*) Concentration giving a 50\% decrease of DPPH radical. The values are the means of triplicate experiment

The methanolic extract of the $P$. acidus, and E. heterophylla showed weak activity as DPPH scavenger. However, when this extract was partitioned between $n$-hexane and aquadest then ethyl acetate and aquadest. The ethyl acetate fraction of the $P$. acidus $P$. buxifolius and $E$. heterophylla $\mathrm{L}$ showed a strong free radical scavenging activity with $\mathrm{IC}_{50}$ value $4,64 \mathrm{ppm}$ and $5.88 \mathrm{ppm}$, respectively. The $n$-hexane fraction of all herbs showed a very weak activity.

Table 3. TLC data for the ethyl acetate fraction by stationary phase celulose

\begin{tabular}{|c|c|c|c|c|c|c|}
\hline \multirow{2}{*}{$\begin{array}{l}\text { Mobile } \\
\text { Phase }\end{array}$} & \multirow[b]{2}{*}{ Plant } & \multirow[b]{2}{*}{ Fraction } & \multirow[b]{2}{*}{ hRf } & \multicolumn{3}{|c|}{ Color of spot TLC } \\
\hline & & & & $\begin{array}{c}\text { UV } \\
366 \mathrm{~nm}\end{array}$ & NH3 & $\begin{array}{l}\text { Citro } \\
\text { Boric }\end{array}$ \\
\hline \multirow{4}{*}{$\begin{array}{l}\text { BAW*) } \\
(4: 1: 5)\end{array}$} & P. acidus & EtOAc & 82 & Yellow & Yellow & Yellow \\
\hline & P. buxifolius & EtOAc & 92 & Yellow & Yellow & Yellow \\
\hline & E. heterophylla & EtOAc & 68 & Brown & Yellow & Yellow \\
\hline & Rutin & EtOAc & 61 & Brown & Yellow & Yellow \\
\hline \multirow{4}{*}{$\begin{array}{c}\text { Acetic acid } \\
15 \%\end{array}$} & P. acidus & EtOAc & 48 & Yellow & Yellow & Yellow \\
\hline & P. buxifolius & EtOAc & 35 & Yellow & Yellow & Yellow \\
\hline & E. heterophylla & EtOAc & 35 & Brown & Yellow & Yellow \\
\hline & Rutin & EtOAc & 50 & Brown & Yellow & Yellow \\
\hline
\end{tabular}


Using two solvent systems, the TLC analysis of ethyl acetat (EtOAc) fraction that as active fraction showed flavonoid compound. The result identification of spot on UV 366 showed yellow and brown color.

\section{DISCUSSION}

In present study, the antioxidant activities of P.acidus, P. buxifolius and E. heterophylla were determined by extraction with methanol and fractination with $n$-hexane and aquadest then ethyl acetate and aquadest. The methods can isolated based-polarity natural compound. As can be seen in Table 3, the studies showed that ethyl acetat fraction include polyphenol as flavonoid. These natural antioxidative substances usually have a phenolic moiety in their molecular structure.

Phenolic antioxidants are potent free radical terminators. Phenolic compounds, biological active components, are the main agents that can donate hydrogen to free radicals and thus break the chain reaction of lipid oxidation at the first inisiation step. This high potential of phenolic compounds to scavenge radical may be explained by their phenolic hydroxyl groups.

The antioxidant activites were obtained from extract methanolic and fractions from methanolic extract. The $\mathrm{IC}_{50}$ values obtained are presentated in Table 2. All of the herbs showed activity as DPPH scavenger. The antioxidant activities of ethyl acetate fraction increased, and greater than that of the same herbs of methanolic extract. Among these herbs, Euphorbia heterophylla L. and Phyllanthus buxifolius Muell, Arg. exhibited a strong free radical scavenging of ethyl acetat fraction with $\mathrm{EC}_{50}$ value $5.88 \mu \mathrm{g} / \mathrm{ml}$ and $4.64 \mu \mathrm{g} / \mathrm{ml}$.

Antioxidant activities of $n$-hexane, ethyl acetat, and aquous fraction were determined by DPPH radical. DPPH is a stable free radical in aquous or methanol solution and aceppts an electron or hydrogen radical to become a stable diamagnetic molecule (Gulcin et al., 2004). In order to evaluate antioxidant potency through free radical scavenging with the test sample, the change in the optical density of DPPH radicals was monitored. Hence, DPPH is usually used as a substrate to evaluate the antioxidative activity of antioxidants (Duh et.al., 1999).

\section{CONCLUSION}

In conclusion, P.acidus, P. buxifolius and E. heterophylla have antioxidant. All of the herbs showed activity as DPPH scavenger. Among these herbs, Euphorbia heterophylla L. and Phyllanthus buxifolius Muell, Arg. exhibited a strong free radical scavenging of ethyl acetat fraction with $\mathrm{IC}_{50}$ value $5,88 \mu \mathrm{g} / \mathrm{ml}$ and 4,64 $\mu \mathrm{g} / \mathrm{ml}$. The result of TLC by mobile phase $n$ buthanol-acetic acid-water (4:1:5) and acetic acid $15 \%$ indicated present of flavonoid compound. Therefore, it is suggested that further work to be performed on the isolation and identification of antioxidative component of ethyl acetat fraction.

\section{ACKNOWLEDGMENT}

We are gratefull to all members on the staff of the Departemen of Pharmaceutical Biology, Setia Budi University and to my students (Louis, Novanita and Noveria) for support to carry out this research.

\section{REFERENCES}

Bartosikova, L., Necas, J., Suchy, V., Kubinova, R., Vesela, D., Benes, L., Illek, J., Salplachta, J., Florian, T., Frydrych, M., Klusakova, J., Bartosik,T., Frana, L., Frana, P. and Dzurova, J., 2003, Antioxidantive Effects of Morine in ischemia-Reperfusion of Kidneys in the Laboratory Rat, Acta Vet. BRNO, 72, 87-94.

Bergman, M., Varshavsky, L., Gottlieb, H.E. and Grossman, S., 200I, The Antioxidant Activity of Aqueous Spinach Extract: Chemical Identification of Active Fractions, Phytochemistry, 58, I43-152.

Cos, P., Calomme, M., Sindambiwe, J.B., Bruyne, T.D., Cimanga, K., Pieters, L., Vlietinck, A.J. and Berghe, D.V., 200I, Cytotoxicity and Lipid PeroxidationInhibiting Activity of Flavonoids, Planta Med., 67, 5I5-519.

Duh, P.D., Tu, Y.Y. and Yen, G.C., 1999, Antioxidant activity of water extract of harng jyur (Chrysanthemum morifolium Ramat), Lebensm,-Wiss.u-Technol, 32, 269-277.

Gulcin, I., Uguz, M.T., Oktay, M., Beydemir, S. and Kufrevioglu, O.I., 2004, Evaluation of 
the Antioxidant and Antimicrobial Activities of Clary Sage (Salvia sclarea L.), Turk I. Agric. For. 28, 25-33.

Kwon, Y.S. and Kim, C.M., 2003, Antioxidant Constituents from the Stem of Sorghum bicolor, Arch. Pharm. Res., 26(7), 535-539.

Oke, J.M. and Hamburger, M.O., 2002, Screening of Some Nigerian Medicinal Plants For Antioxidant Activity Using 2,2, Diphenyl-Picryl-Hydrazyl Radical, AJBR, 5, 77-79.
Pokorny, J., Yanishlieva, N. and Gordon, M., 200I, Antioxidants in Food, Practical Applications, I-123, Wood Publishing Limited, Cambridge, England.

Yagi, A., Kabash, A., Okamura, N., Haraguchi, H., Moustafa., S.M. and Khalifa., T.I., 2002, Antioxidant, Free Radical Scavenging and Anti-inflammatory Effect of Aloesin Derivatives in Aloe vera, Planta Med., 68, 957-960. 